\title{
The Feldstein-Horioka Puzzle, Saving-Investment Causality and International Financial Market Integration
}

\author{
Christopher Tsoukis* \\ University of Hull
}

\author{
Ahmed Alyousha \\ Bahrain Centre for Studies and Research
}

\begin{abstract}
We review the Feldstein-Horioka (1980) approach to the measurement of the degree of international capital mobility by the size of the saving-investment correlation; we conclude that it raises many problems. Instead, we employ Granger causality tests to measure capital mobility using quarterly data for a sample of 7 industrialised economies for a) the post-war period; and b) the 1980s and 1990s. For the cointegrated saving and investment ratios in the entire sample (Australia-UK), causality goes from saving to investment. For the single (German) cointe-grated pair of the 1980s and 1990s, causality runs in the opposite direction. We interpret this as evidence of increased international financial market integration post-1980.
\end{abstract}

- JEL Classifications: F360, F410.

- Key Words: International Financial Market Integration, Capital Mobility, Granger Causality.

\section{Introduction}

The growing international financial market integration and the resulting capital

\footnotetext{
*Corresponding Address: School of Economic Studies, University of Hull, Hull HU6 7RX, UK, Tel: +44-1482 465708, Fax: +44-1482-466216, Email: c.tsoukis@econ.hull.ac.uk

Bahrain Centre for Studies and Research, Bahrain Email: drahmed1@batelco.com.bh. ( 2001-Center for International Economics, Sejong Institution, All Rights Reserved.
} 
mobility across countries has given rise to a mushrooming literature over recent years, for reasons that appear justified. Indeed, the unimpeded international flow of capital has a number of important theoretical and policy-related consequences. It enables the most profitable investment opportunities worldwide to be undertaken and therefore affects relative growth rates and possibly generates convergence. Through the provision of more saving opportunities, it gives rise to efficient and welfare-enhancing diversification of consumption risks. Further-more, it impinges on the incidence of taxation and the ability of macroeconomic policy to have real effects domestically. Furthermore, the choice of optimal exchange rate regime touches (in both theory and history) on that question. ${ }^{1}$ Last but not least, the degree of international capital mobility is necessary as a precon-dition for the validity of the intertemporal approach in macroeconomics, generally, and the way we view the current account, in particular. For overviews, see Feld-stein (1999) and Obstfeld (1998).

Perfect capital mobility may be defined as unfettered international trade in assets (see Obstfeld, 1986; Stulz, 1986). Reasons for its failure include official restrictions, transactions costs, or taxes. Moreover, on top of institutional impediments, limited mobility may be due to home country bias in portfolio formation, ${ }^{2}$ rules of thumb like matching assets and liabilities by currency (Feldstein and Horioka, 1980), (large) country size (see Baxter and Crucini, 1993) or endogenous government policy (current account targeting, see Summers, 1988). There have been various attempts at measuring the extent to which capital flows across borders without impediments. Direct measurements, like in Mathieson and RojasSuarez (1994) and Grilli et al. (1995), show that, broadly speaking, international financial markets have been liberalised during the late 70 s and $80 \mathrm{~s}$ in the developed countries, while they have remained restricted in less-developed ones.

Different, more indirect, approaches at measurement have been surveyed by Obstfeld (1986, 1995): Inter alia, they inspect interest rate linkages among countries, or investigate whether consumption risks have been fully diversified, or examine whether international portfolios are optimally composed. While useful evidence can be gleaned from such approaches (pointing to the fact that international financial markets are increasingly becoming integrated among developed

\footnotetext{
${ }^{1}$ Naturally, capital mobility impinges also on currency movements. Alyousha and Tsoukis (2000b) investigate the role of capital mobility for the 1997 Asian crisis.

${ }^{2}$ Obstfeld (1995) discusses the possible reasons that give rise to the home bias and analyses the concomitant international diversification puzzle.
} 
countries), it is argued that most approaches to measurement are saddled with problems of inconsistency with economic theory and require considerable volume and precision of data. Hence, most of these approaches do not seem to have caught on. Instead, the approach of measurement which seems to have had the greatest impact in initiating a strand of literature is that of Feldstein and Horioka (1980; henceforth FH) who first offered indirect evidence based on the degree of correlation between saving and investment. Apart from relying on data that is amply available, this correlation approach is also directly related to intertemporal trade, as the saving-investment difference equals the current account and hence the accumulation of external assets. In the next section, we review its rationale and the criticisms against it as a valid measurement of the degree of international capital mobility. The bulk of the arguments now point to the con-clusion that examination of the saving-investment correlation is not informative for that purpose.

In this paper, while still focusing on saving and investment ratios, we follow a different approach to the measurement of capital mobility, based on examining their causal ordering. As explained in section 3, the underlying rationale is very similar to that originally put forward by $\mathrm{FH}$ that initiated the measurement of correlation. However, this method is free of the problems that saddle FH-type correlations because it distinguishes between a high correlation as the result of factors unrelated to financial market integration per se (e.g. the need to maintain external solvency, large country size, and the like), and a certain causal ordering as the result of capital mobility itself. We employ quarterly data, in contrast to almost all the previous literature, and hence avoid the serious problems associated with a high degree of temporal aggregation. Our sample consists of 7 countries that are a representative mix of industrialised economies. In view of the fact that financial liberalisation has occurred mostly since 1980 on a major scale, ${ }^{3}$ we perform the tests for the whole of our post-war sample and for the 1980s and 1990s separately.

To preamble, we arrive at mixed findings, namely a general lack of cointegration between (gross) saving and investment ratios; causality going from saving to investment for Australia and the UK in the entire sample; and the opposite causal ordering for Germany post-1980. There is thus some evidence that international

\footnotetext{
${ }^{3}$ Financial liberalisation has been spurred and accompanied by improved communication and transactions technologies, the creation of new financial products and financial deregulation. Evidence of greater international financial market integration post-1975 is offered by Mathieson and Rojas-Suarez (1994), Grilli et al. (1995) and it is corroborated by the indirect measurements surveyed by Obstfeld (1995).
} 
financial markets have become more integrated and that capital mobility has increased in recent decades. As mentioned, Section 2 contains a survey of the relevant literature and a critical review of the validity of this approach to the measurement of the degree of capital mobility. Section 3 proceeds to empirical tests of causality, while Section 4 concludes.

\section{The Feldstein-Horioka puzzle: ${ }^{4}$ A Review ${ }^{5}$}

In their seminal paper of 1980, FH provided evidence that saving and investment ratios are highly correlated across a sample of developed countries (16 members of OECD) for the period 1960-74. They argued that such evidence flies in the face of views that capital is internationally mobile: In a closed economy, saving equals investment. In an open economy with mobile capital, however, saving and investment decisions would be separate: Saving pursues the highest return worldwide while investment, driven by marginal productivity of capital considerations, is financed by the world pool of available loanable funds. The saving-investment correlation should therefore be low in this case. Apart from its policy relevance, the finding of a high correlation would invalidate the intertemporal approach in international macroeconomics which rests fundamentally on the assumption of (perfect) capital mobility.

Empirical work typically (starting from the original FH (1980) paper) begins with cross-section regressions of the form (in obvious notation):

$$
\frac{I_{i}}{Y_{i}}=\alpha+\beta \frac{S_{i i}}{Y_{i}}+u_{i}
$$

The ratios represent period averages and countries are indexed by $i$. The FH finding of $\beta=1$ (statistically) signifies complete lack of mobility whereas $\beta=0$ is the perfect capital mobility case.

This finding has been substantiated by further empirical work using crosssection regressions with period averages, namely by Feldstein and Basccheta (1991, 23 OECD countries, 1974-86), Obstfeld (1995, 22 OECD countries, 197490), Tesar (1991, 24 OECD countries, 1960-86) and Taylor (1996, who uses his-

\footnotetext{
${ }^{4}$ The puzzle arises since the developments in financial markets mentioned above coexist with evidence of capital immobility.

${ }^{5}$ This review is only partial and is mainly meant as an introduction to the approach we follow here. Coakley, Kulasi and Smith (1998) is a wider-ranging survey offering additional information. See also Alyousha and Tsoukis (2000a).
} 
torical series 1850-1992 for 11 OECD countries and Argentina). Obstfeld (1986) presents direct correlations for 7 OECD countries. It appears to be a stylis-ed fact that saving and investment as ratios over GDP are significantly correlated with the regression coefficient $\beta$ (termed the savings retention coefficient by Feldstein and Baccheta, 1991) often insignificantly different from 1 . The extensive list of studies reviewed in Coakley et al. (1998) shows this finding to be robust across time periods (particularly when the data coverage extends to the 1980s and beyond) ${ }^{6}$ and across estimation methods. However, such a close relationship is less evident in non-OECD countries, particularly LDCs, which compounds the puzzle in that financial liberalisation has been much less pronounced among LDCs (see Mathieson and Rojas-Suarez, 1994). Country-by-country and time series studies also confirm these findings; see Alyousha and Tsoukis (2000a) for details.

In other words, there is now a large body of empirical work pointing to the statistically significant nature of (1). Notwithstanding the robustness of the finding, particularly in cross-section regressions, there is no agreement on the validity of the foregoing approach to the measurement of international capital mobility. There is also scepticism as to whether the persistently high correlation is indeed an illustration of low mobility. We next review the criticisms of this approach as a valid measurement of the degree of international capital mobility.

Firstly, various difficulties surround the econometric techniques; such issues are reviewed in Obstfeld (1995) and Taylor (1996). Obviously, saving and investment are both endogenous variables, which is perhaps particularly damaging for the cross-section estimation. ${ }^{7}$ Endogeneity is also an important issue when it comes to the interpretation of the $\beta$ coefficient; see below. Further difficulty with the crosssection estimation stems from the heterogeneity of country experiences across the period (Obstfeld, 1995 Taylor, 1996).

The second objection is related to the economic interpretation, or rather lack of it, of the $\beta$ coefficient in (1): That coefficient has no theoretical foundation nor any obvious connection with any structural parameter associated with preferences or technology. Moreover, it is now well understood that general equilibrium, optimis-

\footnotetext{
${ }^{6}$ The conclusion on robustness across time may not be shared by all authors. See, for instance, the evidence presented by Obstfeld (1986, 1995), Taylor (1996) and Hussein (1998) pointing tentatively to a decreased correlation post-1974. Sarno and Taylor (1998) point out with UK data that there is an empirically useful distinction between short- and long-run correlations.

${ }^{7}$ It has to be noted, however, that Feldstein and Horioka (1980) themselves tested for this without substantially altering their conclusions. Hussein (1998) used appropriate time-series techniques to account for endogeneity and confirmed the long-run correlation for 23 OECD countries, 1960-93.
} 
ing models can yield positively correlated responses of saving and investment to productivity shocks, particularly if they are correlated across countries (Obstfeld, 1986; Mendoza, 1994; Baxter and Crucini, 1993; Razin, 1995). Finally, there is the possibility of omitted variables driving both saving and investment like in-terest rates, demographic variables, growth, the terms of trade, etc.; see the re-views by Obstfeld (1995), Razin (1995), Tesar (1991) and Obstfeld and Rogoff (1996).

Two serious implications arise out of these considerations: As Taylor (1996) notes, there is no natural benchmark for $\beta$, so that only comparison across time of actual correlation estimates, if anything, are meaningful, and not any cardinal interpretation of actual numbers. Second, Mendoza (1994) points out that a certain degree of correlation can be given by more than one configurations of capital mobility and structural parameters; this observational equivalence makes inference on the changing degree of capital mobility across time periods, based on the changing correlation estimate, invalid.

Finally, we turn to an increasingly advocated line of argument that may prove even more scathing in the long term. Among the reasons that have been suggested as sources of the high correlation, is the possibility that, because of the intertemporal budget constraint any economy faces, saving and investment are bound together in the long run. If this is the case, then both cross-section correlations (with data averaged over long periods) will be high and long-term time-series of saving and investment will be cointegrated (Obstfeld, 1995; Coakley et al., 1996). This argument has been formally shown, for cross-section regressions by Jansen (1998). This accords with the analysis of Trehan and Walsh (1991) who show that with a variable real interest rate, stationarity of the current account is a sufficient condition for long-run external solvency. Such arguments have led to the claim that the finding of cointegration between saving and investment (such as reported by Coakley et al., 1996; Coakley and Kulasi, 1998, Taylor, 1996; Jansen, 1996, among others) is due only to the external solvency constraint and is uninformative about the degree of international capital mobility; see Sinn (1992) and Coakley et al. (1996).

\section{Unit Root and Causality Tests}

For all these reasons, it appears that a growing number of researchers are sceptical about the ability of a simple saving-investment correlation and of regressions in the form of (1), either cross-sectional or based on time-series, to 
give useful information about the degree of capital mobility in the world economy and on whether this is changing over time. Recently, a new approach was initiated by Argimon and Roldan (1994) who investigated the (long-run) causal ordering between the saving and investment ratios. The basic insight behind such tests is that the direction of causality between saving and investment differs according to the degree of capital mobility: In closed economies (whereby capital is completely immobile), investment is undertaken with domestic resources only. Hence, the amount of available savings (either current or accumulated) determines investment in the long run. (In the short run, of course, there may be an inverse causal effect due to Keynesian multiplier effects of investment). In contrast, in open economies with fully mobile capital, investment decisions are independent of domestic saving, since they can be financed from the world pool of available savings; in turn, investment determines output and saving in the long term. In both cases, cointegration between saving and investment should hold, as it is a necessary and sufficient condition for causality to exist in at least one way.

Consequently, we examine long-run Granger causality between the saving/GDP ratio and the investment/GDP ratio. A finding of causality running primarily from the former to the latter is indicative of low international capital mobility for the country concerned, while the opposite would be true in the reverse causal ordering. The actual degree can be gauged from the relative strength of each causal effect. As a prerequisite for the examination of Granger causality, we first inspect the series for univariate and multivariate unit roots. Because of increasing financial market integration in the developed world as analysed, but also since the data spans the Bretton-Woods era in which capital mobility was restricted to maintain the fixed exchange rate arrangements (Obstfeld and Taylor, 1997), in addition to testing for capital mobility for the whole sample, this paper will test for capital mobility for the period starting form 1980. The results on the whole sample and from 1980 onwards are presented accordingly.

Our argument rests on the equivalence between cointegrating relationships and some kind of causality or long-run exogeneity: Since Granger causality essentially implies correlation and time precedence, a clear-cut indication of causality would imply that developments in one variable precede those in the other and hence may reasonably be treated as exogenous shocks. Thus, our work is in one respect in the FH tradition, in that the context is a partial equilibrium one, disregarding the effects of omitted variables or more fundamental shocks, such as those considered in general equilibrium models, that may simultaneously affect both series. In 
another respect, or work departs from the FH tradition by refuting their interpretation of the saving-investment correlation. In this way, our approach is consistent with the possibility that a high long-run correlation may arise for reasons that relate to external solvency (Coakley et al., 1996; Trehan and Walsh, 1991). It is also free of the problems of natural benchmark for correlation and observational equivalence. Consequently, our causality tests remain firmly in the spirit of the FH main argument, while arguably avoiding many of the weaknesses of the original, correlation-type measurement.

Our sample consists of quarterly seasonally adjusted data for 7 industrialised economies for the best part of the post-war era: Australia (1959III-97II), Canada (1957IV-98I), Germany (1978II-94II), Japan (1957IV-97IV), Netherlands (1977I98I), United Kingdom (1957IV-98I) and United States (1957IV-98I). This is a representative sample of industrialised economies in the sense that they range from small open economies to larger ones and even to ones like the USA or Japan that may be considered as quasi-closed by the magnitude of their current accountGDP ratios. Our variables are the gross investment-to-GDP and gross saving-toGDP ratios (IR and SR, respectively). The series used in their construction were obtained from the IMF International Financial Statistics; the availability of quarterly GNP data effectively dictated our sample. ${ }^{8}$ Though it may be argued that the use of gross, rather than net, series may artificially increase their correlation (because of the inclusion of capital depreciation in both), this is hardly a problem in our context as cointegration will be the exception rather than the rule.

Recent cointegration analyses of capital mobility are typically based on annual data (among the few exceptions are Miller, 1988 and Gulley, 1992, who only use US data). To our knowledge, ours is the first attempt to address the issue of capital mobility using quarterly data. One obvious advantage is that we minimise the distortion usually identified with temporally aggregated data and the risk of establishing spurious causality links (see Christiano and Eichenbaum, 1987). Additionally, we increase the power of the unit root tests (Perron, 1989, Lahiri and Mamingi, 1995). Thus, part of our contribution is the investigation of the savinginvestment relationship using quarterly data from a larger set of countries than ever before.

\footnotetext{
${ }^{8}$ The series were private consumption $c$ (line 96f), government consumption $g$ (91f), investment $i$ (gross fixed capital formation 93e+change in stocks 93i), GDP (99b.c) and GNP (99a). Then $I R \equiv i / G D P$, $S R \equiv(G N P-c-g) / G D P$. The US data require a slight adjustment since they are given as government consumption+fixed capital formation (91ff) and private fixed capital formation (93ee).
} 
Table 1. Univariate ADF Tests

\begin{tabular}{|llccrc|}
\hline \multirow{2}{*}{ Country } & \multicolumn{3}{c}{ Whole sample } & \multicolumn{2}{c|}{ 1980I to end } \\
\cline { 2 - 6 } & Sample period & IR & SR & IR & SR \\
\hline Australia & 59III-97II & -1.298 & -1.482 & 1.584 & -2.143 \\
Canada & 57IV-98I & -2.416 & -1.645 & -2.622 & -1.917 \\
Germany & 78II-94II & -2.302 & -0.276 & -2.677 & -0.324 \\
Japan & 57IV-97IV & -2.390 & -2.404 & -1.560 & -2.545 \\
Netherlands & 77I-98I & -2.817 & $-4.179 *$ & -2.681 & $-3.017^{*}$ \\
UK & 57IV-98I & -2.014 & -2.069 & -2.720 & -2.400 \\
USA & 57IV-98I & -2.785 & -2.381 & -1.960 & -1.946 \\
\hline
\end{tabular}

A * indicates significance at the $5 \%$ level.

\section{A. Testing for Univariate and Multivariate Unit Roots: The Whole Sample}

The integration property of the series under consideration (SR and IR) is determined with reference to the results of the Dickey-Fuller. The ADF test is based on (2):

$$
\Delta x_{i}=\beta+\alpha x_{t-1}+\sum_{t=1}^{k} \lambda_{i} \Delta x_{t-1}+\varepsilon_{t}
$$

Here $\Delta$ is the difference operator, $x$ can be any of the ratio series. The data on all series are fitted to (2) except that of the Netherlands saving ratio where a trend is added. The truncation lag parameter $k$ is determined using the general-tospecific strategy suggested by $N g$ and Perron (1995). Given that we are using quarterly data, an upper bound on the lag size was set at 8 without any lower bound. The results for the whole sample period are presented in the first part of Table 1. They show that all series are an integrated process of order one except that of the Netherlands saving-GDP ratio.

A major weakness of standard unit root tests emerges when a series has a break in its deterministic component. Such a break was experienced by the German saving-GDP ratio in the early 1990s (the relevant Figure is contained in Alyousha and Tsoukis, 2000a, and is available on request). This may be the product of German re-unification and the rise in government expenditure that accompanied it. In a seminal paper, Perron (1990) found that when the true data generating process (DGP) is $\mathrm{I}(0)$ with the mean value subjected to a change, a unit root test that does not account for the change in the intercept will erroneously fail to reject the null of I(1). Perron (1990) and a set of other studies suggest respecifying the 
Table 2. Multivariate Unit Root (Likelihood Ratio) Tests

\begin{tabular}{|lccccc|}
\hline \multirow{2}{*}{ Country } & \multicolumn{3}{c}{ Whole sample } & \multicolumn{2}{c|}{ 1980I-end } \\
\cline { 2 - 6 } & The Null & Maximum Eigenvalue & Trace & Maximum Eigenvalue & Trace \\
\hline \multirow{2}{*}{ Australia } & $\mathrm{r}=0$ & $36.829^{*}$ & $40.403^{*}$ & 12.371 & 15.247 \\
& $\mathrm{r} \leq 1$ & 3.575 & 3.575 & 2.876 & 2.876 \\
Canada & $\mathrm{r}=0$ & 11.437 & 14.240 & 7.245 & 9.783 \\
& $\mathrm{r} \leq 1$ & 2.803 & 2.803 & 2.538 & 2.538 \\
Germany & $\mathrm{r}=0$ & 10.931 & 10.952 & $14.170^{* *}$ & $14.178^{* * *}$ \\
& $\mathrm{r} \leq 1$ & 0.021 & 0.021 & 0.009 & 0.009 \\
Japan & $\mathrm{r}=0$ & 6.683 & 9.811 & 9.651 & 11.596 \\
& $\mathrm{r} \leq 1$ & 2.949 & 2.949 & 1.946 & 1.946 \\
UK & $\mathrm{r}=0$ & $12.422^{*}$ & $12.424 *$ & 6.558 & 10.522 \\
& $\mathrm{r} \leq 1$ & 0.002 & 0.002 & 3.964 & 3.964 \\
USA & $\mathrm{r}=0 \mathrm{r} \leq 1$ & 9.221 & 16.250 & 6.114 & 10.644 \\
& & 7.029 & 7.029 & 4.530 & 4.530 \\
\hline
\end{tabular}

Notes: An $*$ and $* *$ stand for significant at $5 \%$ and $10 \%$ level respectively.

model by adding dummy variable(s) to (2) to account for the break. The fall in the saving ratio was gradual, so we estimate an innovational outlier model where the structural change is hypothesised to occur gradually. We follow the method of Perron and Vogelsang (1992) which is appropriate for a non-trending series like the German SR and also lets the timing of the break to be determined empirically. For the German SR, the break is shown to have occurred during the third quarter of 1990. The relevant t-statistic of -2.47 fails to reject the null hypothesis that the series is an integrated process of order one.

The unit root results are largely consistent with findings obtained by previous authors (such as Coakley and Kulasi, 1997; Hussein, 1998) using annually aggregated data. These results suggest that except for the Netherlands saving series, neither saving nor investment is close to being a fixed proportion of GDP, i.e. stationary around a mean value. ${ }^{9}$

Following the results of unilateral unit root tests, cointegration tests for SR and IR pairs are conducted for all countries except the Netherlands. Inference on the multivariate unit root is based on Johansens $(1988,1991)$ likelihood ratio test. The order of each VAR is determined using the Schwarz Bayesian Information Criterion. The maximal eigenvalue and trace statistics are presented in the first part of Table 2; significance is determined on the critical values given

\footnotetext{
${ }^{9}$ While there may be good a-priori reasons to suggest that saving and investment ratios are bounded in the long run, and therefore are $\mathrm{I}(0)$ variables, they may not be so in our (finite) sample as the test results suggest.
} 
Table 3. Long Run Causality (Whole sample)

\begin{tabular}{|lrccc|}
\hline \multirow{2}{*}{ Country } & \multicolumn{2}{c}{$\chi(l)$} & \multicolumn{2}{c|}{$F(d, n-k)$} \\
\cline { 2 - 5 } & SR to IR & IR to SR & SR to IR & IR to SR \\
\hline Australia & $26.589^{*}$ & 1.228 & $27.135^{*}$ & 1.253 \\
UK & $4.984^{*}$ & 0.013 & $4.900^{*}$ & 0.014 \\
\hline
\end{tabular}

Notes: Based on Johansen's Likelihood test. An * implies significance at $5 \%$ level.

in Mac-Kinnon (1991). The test shows the presence of a long run relationship between the investment-GDP ratio and the saving-GDP ratio for Australia and the UK. For the other countries, the finding of non-cointegration may be due to the low power of such tests in finite samples; or, possibly, the running of seemingly unsustainable current account positions during our sample period, as in the case of the US.

Implicit in the standard cointegration tests is the assumption that the cointegrating vector is time-invariant. With the German data showing a structural break, the long run relationship between Germany's saving-GDP and investment-GDP ratios is tested using Gregory and Hansens (1996) residual-based test for cointegration. It tests the null that the cointegrating vector is time-invariant against the alternative that the long run vector had a break in its deterministic setup. The results, not shown here but available on request, failed to reject the null that the cointegrating relationship is time-invariant. Based on this, as well as the results of the standard Johanssen test, we can conclude that the German saving and investment ratios do not enter a long-run relation.

The direction of long-run causality between the two ratios is tested by means of the Johansen test. Table 3 presents the results. For both countries in question, the results indicate that over the long run, saving significantly Granger-causes investment, and not vice versa. In other words, there is little capital mobility in these two countries, as the causal relation between saving and investment is similar to that of a closed economy.

Concluding, wherever long-run causality tests are possible, they point to little capital mobility in the post-war period. These results are generally in agreement with those reported in Obstfeld and Taylor (1997) who find that the Bretton Woods era has been one of historically low international capital mobility. In the many cases where cointegration has not been achieved, though, we remain agnostic over the degree of capital mobility. We next examine whether that picture changed sub-stantially starting from the early 1980s. 
Table 4. Long Run Causality (1980I-end of the sample)

\begin{tabular}{|lcccc|}
\hline \multirow{2}{*}{ Country } & \multicolumn{2}{c|}{$\chi(l)$} & \multicolumn{2}{c|}{$F(d, n-k)$} \\
\cline { 2 - 5 } & SR to IR & IR to SR & SR to IR & IR to SR \\
\hline Germany & 2.770 & $4.504^{*}$ & 2.750 & $4.536^{*}$ \\
\hline
\end{tabular}

Notes: Based on Johansens Likelihood test. An * implies significance at $5 \%$ level.

\section{B. Testing for Univariate and Multivariate Unit Roots: From 1980I Onwards}

Similar tests and strategies are followed in testing for capital mobility for the post-1979IV era. The univariate integration tests point to similar results as those obtained for the whole sample using the Dickey-Fuller tests (see Table 1). Again, for the German saving ratio, the test for structural break failed to reject the null of unit root (t-statistic $=-2.30)$. As in the case of the whole sample, cointegration analysis is carried out for 6 countries. The results for this period find a less pronounced long-run relation between the two ratios. The likelihood ratio test now strongly rejects the null of no cointegration for Germany and fails to reject it for all other countries. Once again, our results on the lack of cointegration, particularly for the 1980I-onwards era, is open to interpretation. It may be consistent with the fact that some of the economies in question continue to run large current account deficits or surpluses which appear unsustainable in our time horizon. The disappearance of cointegration in the cases of Australia and the UK occurs in parallel with the findings of descriptive analyses of increasing international financial market integration. Since accumulating unsustainable external positions involves international asset trade anyway, we could interpret this result as evidence of increased capital mobility in the 1980s and 1990s.

Additionally, as the German saving ratio has a break, that long run relationship is re-tested using the Gregory-Hansen test. The result (again not shown for economy of space) also failed to reject the null of no cointegration. The German case is therefore the only one that permits long run causality tests; those were conducted using the Johansen procedure. The outcome (see Table 4) points to a specific causal ordering that is in tandem with perfect capital mobility, i.e.. that causality runs from investment to saving. The result of a high capital mobility in Germany in recent years is the only one in this direction that we are able to find.

\section{Conclusions}

This paper addresses international capital mobility and its measurement by the 
use of Granger causality tests among the saving-GDP and investment-GDP ratios. Our argument is that inference on the degree of capital mobility can be made from the causal ordering between the two ratios: Causality running from saving to investment would be an indication of an effectively closed economy, while the opposite causal direction would imply international movement of capital. The rationale is essentially the same as that invoked by Feldstein and Horioka (1980). To our knowledge, such tests overcome many of the difficulties saddling traditional, FH-type correlation measurements, as reviewed in Section 2, but have only been employed in empirical work by Argimon and Roldan (1994). Importantly, cointegration needs to be examined as a prerequisite for causality to exist. Unlike most time series work in this area, we utilise quarterly data of the post-war period (in all cases running up to the end of 1997) for a representative sample of 7 industrialised countries.

The results for two periods (full sample and post-1980I) raise considerable ambiguity about cointegration between the saving and investment ratios. As pointed out in section 2 , such mixed evidence in country-by-country savinginvestment cointegration is not uncommon and raises at least the possibility of unsustainable external positions for a number of these economies. However, proper investigation of external solvency and related issues is beyond the scope of this paper. A different interpretation of non-cointegration may center on the low power of tests in finite samples; or that it is quite consistent with intertempotal optimisation during finite samples when consumption-tilting is present (see the intertemporally optimising model of Obstfeld and Rogoff, 1996).

Where cointegration is obtained for the whole of the sample (Australia and UK), Granger-causality tests are possible and show causality to run from saving to investment, indicating little capital mobility. For the post-1980I period, cointegration is found only for Germany and in this case causality runs from investment to saving. Hence, our overall conclusion is that there is little concrete evidence of capital mobility for the 7 industrialised countries in our complete sample. On these grounds, we support the general findings of Feldstein and Horioka (1980) and of the subsequent literature for the post-war period in its entirety. Yet, capital mobility evidently increases for Germany post-1980I. Moreover, cointegration is lost post-1980 even for Australia and the UK. Such persistent current account imbalances for these countries make the detection of a long-run saving-investment causal relation difficult. However, they may possibly be the product of financial liberalisation, in which case, together with the German causality evidence, such 
external asset build-ups do indicate that international capital mobility has increased in the post-1980 era. In all, there is some evidence that financial markets have become more integrated and globalised in the post-Bretton-Woods era, in line with the conclusions of Obstfeld and Taylor (1997).

\section{Acknowledgements}

This is a revised version of the paper presented at the inaugural IEFS (UK) Conference, City University, London, April 1999, on "Capital and Labour Mobility in Europe". We have benefited from participants' comments, and those of George Aghiomirgianakis, Jerry Coakley, Chris Ioannides and Mike Jenkins whom we wish to thank.

Date accepted: December, 2000

\section{References}

Alyousha, A. and C. Tsoukis (2000b), A Re-Examination of Saving-Investment Relationships: Cointegration, Causality and International Capital Mobility, Hull Economics Research Paper, forthcoming.

Alyousha, A. and C. Tsoukis (2000a), The Genesis of the Crisis: The External Solvency of the Tiger Economies, forthcoming in Simon Lee ed.: The Political Economy of the South East Asian Crisis, Lynne Rienner, forthcoming.

Argimon, J. and J. Roldan (1994), "Saving, Investment and International Capital Mobility in EC Countries," European Economic Review, 38; 59-67.

Baxter, M. and M. Crucini (1993), "Explaining Saving-Investment Correlations," American Economic Review, 83(3); 416-36.

Christiano, L. and M. Eichenbaum (1987), Temporal Aggregation and Structural Inference in Macroeconomics, in K. Brunner and A. Meltzer eds, Bubbles and Other Essays, Cranegie-Rochaster Conference Series on Public Policy, 26; 63-130.

Coakley, J, F. Kulasi (1997), "Cointegration of Long Span Saving and Investment," Economic Letters, 54; 1-6.

Coakley, J. F., Kulasi and R. Smith (1996), "Current Account Solvency and the SavingInvestment Puzzle,” Economic Journal, 106; 620-7.

Coakley, J. F., Kulasi and R. Smith (1998), "The Feldstein-Horioka Puzzle and Capital Mobility: A Review," International Journal of Finance and Economics, 3; 169-88.

Engle, R. and C. Granger (1987), "Co-integration and Error Correction: Representation, Estimation and Testing," Econometrica, 55; 251-76.

Feldstein M. (1999), "International Capital Flows: Introduction,” in his ed.: International 
Capital Flows, Chicago: The University of Chicago Press for NBER.

Feldstein M. and P. Bacchetta (1991), "National Saving and International Investment," in B. D. Bernheim and J. B. Shoven eds., "National Saving and Economic Performance," Chicago, Chicago UP, 201-20.

Feldstein M. and C. Horioka (1980), "Domestic Saving nd International Capital Flows," The Economic Journal, 90; June, 314-29.

Finn M. (1990), "On Savings and Investment Dynamics in a Small Open Economy," Journal of International Economics, 29; August, 1-21.

Ghosh, A.R. (1995), "International Capital Mobility Amongst the Major Industrialised Countries: Too Little or Too Much?” Economic Journal, 105; 107-28.

Gregory, A. and B. Hansen (1996), "Residual Based Tests for Cointegration in Models with Regime Shifts,” Journal of Econometrics, 70; 99-126.

Grilli, V. and G.M. Milesi-Ferretti (1995), Economic Effects and Structural Determinants of Capital Controls, IMF Staff Papers, 42; 3 (September), 517-51.

Gulley, D.O (1992), "Are Saving and Investment Cointegrated? Another Look at the Data," Economics Letters, 39; 55-58.

Gundlach, E. and S. Sinn (1992), "Unit Root Tests of the Current Account Balance: Implications for International Capital Mobility," Applied Economics, 26; 617-25.

Hussein, K. (1998), "International Capital Mobility in OECD Countries: The FeldsteinHorioka Puzzle Revisited," Economic Letters, 59; 237-42.

Jansen, W. (1997), "Can the Intertemporal Budget Constrain Explain the FeldsteinHorioka Puzzle?" Economic Letters, 56; 77-83.

Johansen, S. (1988), "Statistical Analysis of Cointegration Vectors," Journal of Economic Dynamics and Control, 12; 231-54.

Johansen, S. (1991), 'Estimating and Hypothesis Testing of Cointegration Vectors in Gaussian Vector Autoregressive Models," Econometrica, 59; 1551-80.

Kenen P., (ed.), (1995), Understanding Interdependence, Princeton: Princeton UP.

Lahiri, K. and N. Mamingi (1995), "Power Versus Frequency of Observation-Another View," Economics Letters, 49; 121-4.

Leiderman, L. and A. Razin (eds.), (1994), Capital Mobility: The Impact on Consumption, Investment and Growth, Cambridge: CUP.

MacKinnon, J. (1991), "Critical Values for Cointegration Tests," in R. Engle and C. Granger eds, Long Run Economic Relationships: Readings in Cointegration, Oxford University Press, Oxford, 267-76.

Mathieson, D. J. and L. Rojas-Suarez (1994), Liberalisation of the Current Account: Experiences and Issues, in Leiderman and Razin (1994) .

Mendoza E. (1994), in Leiderman and Razin (1994), The Robustness of Macroeconomic Indicators of Capital Mobility.

Miller, S.M. (1988), “Are Saving and Investment Cointegrated?” Economics Letters, 27; 31-34.

Obstfeld, M. (1986), "Capital Mobility in the World Economy: Theory and Measurement," Carnegie-Rochester Conference Series on Public Policy, 24 (Spring), 55-104. 
Obstfeld, M. (1998), “The Global Capital Market: Benefactor or Menace?” Journal of Economic Perspectives, 12(4); 9-30.

Obstfeld, M. (1994), “Are Industrial-Counrty Consumption Risks Globally Diversified?," in Leiderman and Razin (1994).

Obstfeld, M.(1995), International Capital Mobility in the 1990s, in P. Kenen (1995), 201-61.

Obstfeld, M. and K. Rogoff (1996), The Intertemporal Approach to the Current Account, Ch. 34 in G. Grossman and K. Rogoff (eds.), (1996), Handbook of International Economics Vol. III, Amsterdam: Elsevier.

Obstfeld, M. and A. Taylor (1997), The Great Depression as a Watershed: International Capital Mobility over the Long Run, CEPR Discussion Paper No. 1633.

Perron, P. (1989), Testing for the Random Walk: A Simulation Experiment With the Sampling Interval is Varied, in B. Raj (ed), Advances in Econometrics and Modelling, Kluwer, Dordrecht, 47-68.

Perron, P. (1990), Testing for Unit Root in a Time Series with a Changing Mean, Journal of Business and Economic Statistics, 8; 153-62.

Perron, P. and Vogelsang (1992).

Pesaran, M., Y. Shin and R. Smith (1996), Testing for the Existence of Long-Run Relationships, DAE Working Paper No. 9622, Department of Applied Economics, University of Cambridge.

Phillips, P, and P, Perron (1988), Testing for a Unit Root in Time Series Analysis, Biometrika, 75; 335-46.

Razin A. (1994), The Dynamic-Optimizing Approach to the Current Account: Theory and Evidence, in P. Kenen (1995).

Rodrik, D. (1998), Symposium on Globalization in Perspective: An Introduction, Journal of Economic Perspectives, 12(4); 3-8.

Sarno_L. and M.P. Taylor_(1998), Savings-investment correlations: transitory versus permanent Manchester School, 66 (Suppl.), 17-38.

Sinn S., (1992), Saving-Investment Correlations and Capital Mobility: On the Evidence from Annual Data, Economic Journal, 102, September, 1162-70.

Stulz R. (1986), Capital Mobility in the World Economy: Theory and Measurement: A Comment, Carnegie-Rochester Conference Series on Public Policy, 24(Spring); 105119.

Summers L.H. (1988), Tax Policy and International Competitiveness, in J. Frenkel (ed.): International Aspects of Fiscal Policies, Chicago, Chicago UP, 349-75.

Taylor, A.M. (1996), International Capital Mobility in History: The Saving-Investment Relationship, NBER Working Paper 5743, September.

Tesar, L. (1991), Savings, investment and international capital flows, Journal of International Economics, 31; 55-78.

Trehan, B. and C.E. Walsh (1991), Testing Intertemporal Budget Constraints: Theory and Applications to U.S. Federal Budget and Current Account Deficits, Journal of Money, Credit and Banking, 23; 2 (May), 206-23. 